The Historical Journal, 63, 2 (2020), pp. 411-436 (C) Cambridge University Press 2019. This is an Open Access article, distributed under the terms of the Creative Commons Attribution licence (http://creativecommons.org/licenses/by/4.o/), which permits unrestricted re-use, distribution, and reproduction in any medium, provided the original work is properly cited.

doi: $10.1017 /$ SoO $18246 X_{19000281}$

\title{
WHITE ANTS, EMPIRE, AND ENTOMO-POLITICS IN SOUTH ASIA*
}

\author{
ROHAN DEB ROY \\ University of Reading
}

\begin{abstract}
A B ST R A C T. By focusing on the history of white ants in colonial South Asia, this article shows how insects were ubiquitous and fundamental to the shaping of British colonial power. British rule in India was vulnerable to white ants because these insects consumed paper and wood, the key material foundations of the colonial state. The white ant problem also made the colonial state more resilient and intrusive. The sphere of strict governmental intervention was extended to include both animate and inanimate non-humans, while these insects were invoked as symbols to characterize colonized landscapes, peoples, and cultures. Nonetheless, encounters with white ants were not entirely within the control of the colonial state. Despite effective state intervention, white ants did not vanish altogether, and remained objects of everyday control until the final decade of colonial rule and after. Meanwhile, colonized and post-colonial South Asians used white ants to articulate their own distinct political agendas. Over time, white ants featured variously as metaphors for Islamic decadence, British colonial exploitation, communism, democratic socialism, and, more recently, the Indian National Congress. This article argues that co-constitutive encounters between the worlds of insects and politics have been an intrinsic feature of British colonialism and its legacies in South Asia.
\end{abstract}

Published in London a year before the Sepoy Mutiny of 1857 , a book described how the governor general's residence in Calcutta, then capital of British India, was attacked by unforeseen enemies. It lamented that these assailants had already undermined the suzerainty of the British empire on numerous occasions. After having established their 'dominions... on terra firma', they 'took possession' of British ships, and were now on the verge of asserting their 'sovereignty of the ocean'. On the other side of the world in the West Indies, these intruders had made their way into the house of the British governor of Tobago, and even 'took possession' of a microscope that was carefully preserved

Department of History, School of Humanities, Whiteknights Campus, University of Reading, Reading, RG66AA rohan.debroy@gmail.com

* I thank the anonymous readers for the Historical Journal and the editors for their comments. I also thank Shinjini Das, Daniel Renshaw, Charlotte Sleigh, Jonathan Saha, Simon Schaffer, Jim Secord, Erica Wald, Rohit De, Rajarshi Ghose, and Upal Chakrabarti for their helpful suggestions. 
within a mahogany box. ${ }^{1}$ Their ability to trespass into some of the most securely barricaded enclaves of empire and cause havoc amazed Dionysius Lardner, the author of this monograph.

Lardner, who had been a significant figure in the popularization of scientific knowledge in London, was describing the exploits of termites, a group of insects referred to interchangeably and more commonly as white ants. He shared the widely held contemporary understanding that white ants were a distinct group of insects that had 'very little in common with ants' except perhaps their perceived 'social character and habits'. ${ }^{2}$ Although he was silent about the complexion of white ants, other nineteenth-century observers doubted if these insects were necessarily white in colour. ${ }^{3}$ Lardner observed that despite possessing four membranous wings in their 'perfect state', white ants were 'diminutive' in size, hardly a quarter of an inch in length, were usually blind, and were composed of a soft body wrapped up by a 'thin and delicate skin'. Lardner argued that given their vulnerable physical constitution they felt threatened even by ants, and retreated mostly to a covert and subterranean existence. 4

White ants were indeed tiny, fragile, and relatively invisible insects. Yet, they made their formidable presence felt across the British empire, whether in Africa, Australia, or Southeast Asia. ${ }^{5}$ Encounters between British imperial power and white ants were enduring, significant, and multifaceted. In view of the indelible scars left by white ants on artefacts that were fundamental to the sustenance of empire, contemporary commentators tended to magnify the physical properties of these otherwise fragile insects. White ants were thus compared with bulldogs and imagined to possess forceps. ${ }^{6}$

Although many works on British colonial history refer to white ants in passing, in-depth focus on the history of white ants in the colonial context is rare. 7 Even

${ }^{1}$ Dionysius Lardner, The bee and white ants, their manners and habits; with illustrations of animal instinct and intelligence (London, 1856), pp. 121 and 119.

${ }^{2}$ Lardner, The bee, p. 98; James Rennie, Insect architecture (London, 1830), p. 291; W. Farren White, Ants and their ways (London, 1883), p. 235.

3 H. A. Hagen, 'The probable danger from white ants', American Naturalist, 10 (1876), pp. 401-10, at pp. 401-3; EHA, 'The tribes on my frontier: white ants', Times of India (TOI), 19 Mar. 1881 , p. 2.

4 Lardner, The bee, pp. 98, 110-11, 117

5 For example, John W. Lloyd, Copy of diary no. vii (St Helens, 19o8), pp. 16-19; John Pickard, 'Post and rail fences: derivation, development and demise of rural technology in colonial Australia', Agricultural History, 79 (2005), pp. 27-49, at pp. 33, 40, 43; Peter Triantafillou, 'Governing agricultural progress: a genealogy of the politics of pest control in Malaysia', Comparative Studies of Society and History, 43 (2001), pp. 193-221, at p. 199.

6 James Skipp Borlase, Stirring tales of colonial adventure: a book for boys (London, 1894), p. 229; George Watt, A dictionary of the economic products of India, vI, part II (Calcutta, 1893), p. 125.

7 For an exception, see Deirdre Coleman, Romantic colonization and British anti-slavery (Cambridge, 2009), pp. 28-62. See also Starr Douglas and Felix Driver, 'Imagining the tropical colony: Henry Smeathman and the termites of Sierra Leone', in Felix Driver and Luciana Martins, eds., Tropical visions in an age of empire (Chicago, IL, 2005), pp. 91-112. Charlotte Sleigh's work on ants and John Clark's introduction to his work on insects in Victorian culture succinctly indicate colonial metaphorical uses of white ants. See Charlotte Sleigh, 
fewer attempts have been made in examining the sustained interactions between white ants and imperial power in a specific British colony. In adopting such an approach with respect to British India in the nineteenth and early twentieth centuries, this article analyses different facets of colonial power that these interspecies interactions engendered. The first section explores the vulnerabilities of British colonial rule to white ants. From the early nineteenth century onwards, white ants were seen increasingly to affect the fledgling networks of colonial bureaucracy and infrastructure. Analysis of these vulnerabilities, in turn, brings to the fore some of the key material foundations of colonial power. The second section emphasizes the resilience of the British colonial state by examining the strategies authorized by officials to address the problem of white ants. These strategies reveal how the gaze of colonial governance was extended to include the realm of animate as well as inanimate nonhumans. While the relevance of these strategies persisted throughout the colonial period, newer trends were witnessed in the course of the nineteenth century. The third section, therefore, traces how British columnists, bureaucrats, and naturalists appropriated the white ant problem as an opportunity to characterize Indian landscapes and people. In imperial rhetoric, white ants featured as a metaphor to articulate political antagonism, social disapproval, and civilizational differences. The final section highlights that the colonial state could not entirely dictate the metaphorical uses of white ants in British India. Even when adopting these rhetorical strategies in colonial and post-colonial India, South Asians reshaped them. A range of South Asians have referred to white ants to bolster their own political positions.

Using the case of white ants, this article highlights how entomo-politics was an intrinsic feature of colonial power. Entomo-politics may serve as a pertinent expression to indicate ubiquitous encounters between insects and political power. As part of the broader field of animal and environmental histories, the focus on entomo-politics questions the predominant anthropocentrism in the mainstream historiography of empire. ${ }^{8}$

The expression entomo-politics indicates the processes through which the diverse realm of insects was acknowledged, shaped, and dealt with in the political domain in the nineteenth and twentieth centuries. In view of their perceived paradoxical and enigmatic characteristics, insects more generally were considered distinct within the wider category of non-human animals. ${ }^{9}$ One of

\footnotetext{
'Empire of the ants: H. G. Wells and tropical entomology', Science as Culture, 10 (2001), pp. 3371, at pp. 33-6; John F. M. Clark, Bugs and the Victorians (New Haven, CT, 2009), pp. 2-6.

${ }^{8}$ For overviews, see, for example, James Beattie, 'Recent themes in the environmental history of the British empire', History Compass, 10 (2012), pp. 129-39; Aaron Skabelund, 'Animals and imperialism: recent historiographical trends', History Compass, 11 (2013), pp. 801-7; Jonathan Saha, 'Colonising elephants: animal agency, undead capital and imperial science in British Burma', British Journal for the History of Science Themes, 2 (2017), pp. 169-89.

${ }^{9}$ On the distinctive paradoxical features that characterize the diverse world of insects, see Hugh Raffles, Insectopedia (New York, NY, 2010), pp. 3-4.
} 
these paradoxical characteristics related to the scale of insects as historical actors. Although insects were usually miniscule in size, they were innumerable. Despite their apparently fragile and ephemeral bodies, insects were recurrent and almost pervasive. ${ }^{10}$ Political establishments, especially in the tropical colonies, interpreted insects diversely because of their alleged excessiveness. While various species of insects were suspected of being medical and agricultural pests, others were valued as potential commercial resources and lively capital. $^{11}$ The enigma about insects percolated into the fields of knowledge. Entomologists debated whether insects were the least evolved among living creatures, or whether they constituted ideal models for technological as well as human social organization; whether insects were endowed with traces of intelligence or whether they were instinct-driven machine-like automatons. ${ }^{12}$ Given the ascription of such commodious attributes, insects have served as enduring political and social metaphors, which were often connected to practices of dehumanization and zoomorphism. ${ }^{13}$

The term entomo-politics also opens up for analysis the extent to which political power and insects were co-constituted. While highlighting the political and cultural contexts in which the natural characteristics of insects were defined, experienced and contested, the frame of entomo-politics also reveals how the persistent presence of these tiny and lively creatures was unavoidable in the shaping of the vocabulary and practices of political power.

Some scholars have recently argued that insects are particularly 'good to think with'. ${ }^{4}$ This article traces the emergence of white ants as entomo-political subjects in South Asia to rethink British colonial rule in the region. In so doing, it details how these insects and colonial power shaped one another. As will be shown, these co-constitutive processes manifested in different ways. White ants made colonial power vulnerable. Yet, white ants also made colonial power more prolific as a source of metaphors, more vigilant, resilient, and intrusive. Because of their entanglement with colonial and post-colonial politics, white ants, in turn, featured as miniscule, numerous, and recurrent pests, and

${ }^{10}$ On ephemeral, see Jussi Parikka, Insect media: an archaeology of animals and technology (Minneapolis, MN, 2010), p. xxxiv.

${ }^{11}$ Sheila T. Wille, 'Governing insects in Britain and the empire, 1691-1816' (Ph.D. thesis, Chicago, 2014); Triantafillou, 'Governing agricultural progress'; Clark, Bugs, pp. 187-214; Robert Fletcher, 'The locust, the empire, and the museum', evolve, 31(2017), pp. 46-53; Clapperton Chakanetsa Mavhunga, The mobile workshop: the Tsetse fly and African knowledge production (Minneapolis, MN, 2018); Edward D. Melillo, 'Global entomologies: insects, empires and the "synthetic age" in world history', Past and Present, 223 (2014), pp. 233-70.

12 Clark, Bugs, pp. 34-53, 54-79, 97; Charlotte Sleigh, Six legs better: a cultural history of myrmecology (Baltimore, MD, 2007), pp. 44-61; Parikka, Insect media, pp. x-xii, xv-xvi, 3-8, 19-20, 24-3o, 32-43, 49-5 .

13 Hugh Raffles, 'Jews, lice and history', Public Culture, 13 (2007), pp. 521-66; Eric C. Brown, ed., Insect poetics (Minneapolis, MN, 2006); Sleigh, 'Empire of the ants', pp. 33-71.

14 Uli Beisel, Ann Kelly, and Noemi Tousignant, 'Knowing insects: hosts, vectors and companions of science', Science as Culture, 22 (2013), pp. 1-15, at pp. 1, 3, 12, 13. 
as objects of knowledge and governmental control. In the process, white ants acquired a range of cultural meanings. Over time, white ants were projected as a marker of primitive civilizations and Islamic misrule, and as an allegory for British imperial exploitation, communism, democratic socialism, and even the Indian National Congress.

Imperial officials in different parts of British India persistently complained about white ants. These 'ravenous' insects supposedly 'damaged', 'destroyed', and 'ravaged' bamboo, cloth, glass, leather, tiles, thatched roof, and even wool. ${ }^{15}$ They interfered with the activities of colonial officials in a range of sites including warehouses, military stores and stables, and sub-divisional offices. The British empire in India appears to have been particularly vulnerable to white ants because these insects consumed paper and wood, which were amongst the most crucial material foundations of the nineteenth-century colonial state.

Paper was one of the backbones of the colonial bureaucracy. ${ }^{16}$ In the Company era, officials alleged that white ants destroyed different kinds of materials that were made of paper: currencies as well as promissory notes, handwritten revenue and judicial records. ${ }^{17}$ Therefore, white ants added to the everyday chaos of the administration. The issue of white ants was recurrently discussed in bureaucratic files. White ants also potentially threatened the very existence of these files themselves. Despite the proliferation of print and related copying

15 Court of Directors, East India Company, London (COD) to president in council at Fort St George, Madras (CFSG), paragraph (para.) 18, 24 Dec. 1765 , IOR/E/4/863, p. 239 (British Library: archives and manuscripts (BL)); governor in CFSG (GCFSG) (Military) to COD, para. 323, 2 Apr. 1817, paraphrased in COD to GCFSG (Military), 8 Apr. 1819, IOR/E/4/922, p. 778 (BL); GCFSG (Military) to COD, para. 57 of letter 25, 2 Aug. 1831, paraphrased in COD to GCFSG (Military), despatch 589 (82 of 1832 ), 24 Oct. 1832 , IOR/E/4/942, p. 121 (BL); Bengal (Military) to COD, paras. $14^{-15}$ of letter 70,27 Apr. $185^{\mathrm{O}}$, paraphrased in COD to Bengal (Military), despatch 729 (113 of $185^{\circ}$ ), 23 Oct. $185^{\circ}$, IOR/E/4/8o6, p. 1136 (BL); India (Revenue) to COD, para. 244, letter 6, 5 July 1855 , paraphrased in COD to North Western Provinces, India (Revenue), despatch 1390 ( 1 of 1857 ), 7 Jan. 1857 , IOR/E/4/841, p. 474 (BL); G. Bidie, 'White ants', Nature, 26 (5 Oct. 1882), p. 542; Anonymous, 'Untitled', TOI, 9 Feb. 1875, p. 2.

${ }^{16}$ For example, Bhavani Raman, Document Raj: writing and scribes in early colonial South India (Chicago, IL, 2012); Hayden J. Bellenoit, The formation of the colonial state in India: scribes, paper and taxes, I760-1860 (Abingdon, 2017); Berenice Guyot-Rechard, 'Tour diaries and itinerant governance in the eastern Himalayas, 1909-1962', Historical Journal, 6o (2017), pp. 1023-46.

17 India (Revenue) to COD, paras. 147-66, letter 8, 10 Nov. 1835 , paraphrased in COD to India (Revenue), para. 43, despatch 1 of 1838 , 20 Mar. 1838 , IOR/E/4/754, pp. $264-5$ (BL); paraphrased in COD to India (Financial), para. 8, despatch of $185_{1}^{1,} 22 \mathrm{Jan} .185^{1}$, IOR/E/4/ 8o7, pp. 1279-8o (BL); Bombay (Revenue) to COD, letter 62, 13 Nov. 1839, IOR/F/4/1901/ $8085^{2}$, p. 1 (BL); Fort St George (FSG) (Judicial) to COD, para. 26, letter 9, 6 Dec. year not mentioned, paraphrased in COD to FSG (Judicial), despatch 308 (8 of 1844), 31 May 1844 , IOR/E/4/961, p. 955 (BL). 
technologies in the post-mutiny period, these anxieties did not entirely subside. Administrative concerns about protecting printed bureaucratic reports from white ants persisted throughout the colonial period. ${ }^{18}$

The ostensible appetite of white ants for paper interrupted significant intellectual projects that were initiated by the government. The production as well as preservation of knowledge about India was among the key modalities of British colonial rule in the subcontinent. The colonial government upheld itself as a patron of books relating to India. White ants made their presence felt in some of these projects. In the early nineteenth century, for example, the public department in the Bombay presidency commissioned Captain James Thomas Molesworth to produce a Marathi to English dictionary for the benefit of East India Company employees in the region. Before the dictionary could be widely circulated, 149 rare copies 'suffered to be devoured by the white ants'. ${ }^{19}$

Later in the century, the fact that white ants could notoriously 'devour books wholesale'2o particularly bothered the Indian museum in Calcutta, which pursued the ambition of 'permanent preservation' of exhibits, including books and manuscripts, from the 'ravages' of white ants. ${ }^{21}$ It was also feared that alongside damaging government documents white ants were perniciously destroying memories of earlier phases of British rule in India. An article published in the Times of India in 1874 , for instance, lamented that documents related to Calcutta in the pre-1770 period had been 'swept away' by white ants. ${ }^{22}$

Compared to paper, the significance of wood as a foundation of empire is relatively less recognized in recent historiography. Yet, the vulnerability of British colonial rule in India to white ants resulted especially from the fact that it was an empire based, to a great extent, on woodwork. Colonial officials variously recorded that white ants tended to 'attack' and 'destroy' wood.

Wood was a key material foundation of the infrastructures of transport and communication that the colonial government had put together. Timber was an essential ingredient of ships that visited sub-continental ports in the Company era. Officials from the period alleged that by preying on wood, white ants caused severe damage to steam vessels. Ships were 'docked' after being 'attacked' by these 'troublesome insects', and repairing them involved

18 Report on the land revenue administration of the Punjab for the year ending the 3 oth September, I940 (Lahore: Superintendent, Government Printing, Punjab, 1941), p. 17, IOR V/24/ $2484(\mathrm{BL})$.

${ }_{19}$ COD to Bombay (Public), despatch 8 of 1836 , 1 o Feb. $18_{3} 6$, IOR/E/4/1059, pp. $9^{6} 3^{-9}$ (BL).

${ }^{20}$ E. C. Cotes, 'Miscellaneous notes from the entomological section', Indian Museum Notes, 3 (1894), pp. $110-41$, at p. 115 .

21 Anonymous, 'The India museum and library, and the measure required for their efficient working and proper accommodation', p. 32 , in Memoranda and papers laid before the council of India, 17 Jan. 1874-1 1 Jan. 1875, IOR/C/137 (BL).

22 Anonymous, 'A hundred years ago: Calcutta in 1760-70', TOI, 17 Aug. 1874, p. 4 . 
substantial expenditure in the 1820 and 183 os. The estimated costs for repairing them ranged between 1,497 rupees and 35 ,ooo rupees. ${ }^{23}$ The occasional crippling of these spectacular symbols of British industrial technology by tiny insects disrupted the seamless display of imperial power.

White ants made their presence felt in the ever-expanding network of railways from the 184 os onwards. In 1857 , officials inquired about how a railway bridge made of creosoted timber in Serampore in Bengal underwent decay after one of its fir piles was 'attacked' by white ants. ${ }^{24}$ Around this time, it was also alleged that white ants 'destroyed' sleepers made of wood after making their way into railway carriages. ${ }^{25}$ Meanwhile, officials based in Punjab and elsewhere reported that white ants intruded within the expanding apparatus of electric telegraph by 'ravaging' wooden posts. ${ }^{26}$

The use of wood by colonial officials went beyond framing mechanisms of long-distance travel and communication. This explains why these officials had to deal with the indelible marks left by white ants not just on military storages in the Company era, but also on public buildings and packages at a later period. ${ }^{27}$ For example, white ants damaged powder racks in the arsenal of Fort William in Calcutta in 1856 , as well as subjecting wooden staves of barrels containing gunpowder to 'destructive attack' a few years earlier in a military store in Madras. ${ }^{28}$

White ants featured in discussions about grand colonial administrative schemes. A 681 mile long 'customs hedge', which existed over considerable parts of northern India until the final quarter of the nineteenth century, was designed as an 'impenetrable and permanent barrier' against smuggling supposedly undertaken by colonized Indians across British Indian frontiers. In 1867-8, Allan Octavian Hume, the commissioner of inland customs, cited

23 Anonymous, 'White ants in the Magdala', TOI, 16 Oct. 1875, p. 2; Anonymous, 'Interesting experiment at Hog Island', TOI, 10 Apr. 1879, p. 3; Marine Board to Bentinck, 6 Jan. 1829 , IOR/F/4/1308/51968, pp. 5-10 (BL); Bengal (Public) to COD, paras. 31-7 of letter 12, 13 Mar. 1835, paraphrased in COD to Bengal (Public), para. 1 of despatch 12 of 1836,3 Feb. $18_{3} 6$, IOR/E/4/746, pp. 1085-92 (BL).

${ }_{24}$ COD to India (Financial, Railway), para. 23 , despatch 14 of 1858,21 Apr. 1858 , IOR/E/ $4 / 85^{1,}$, pp. $5^{\mathrm{O} 2-3}$ (BL).

25 Anonymous, 'Madras: sleepers for Indian railways', TOI, 14 Sept. 1859 , p. 588.

${ }^{26}$ For example, COD to India (Electric Telegraph), despatch 531 (no. 10 of 1857 ), 20 May $1857, \mathrm{IOR} / \mathrm{E} / 4 / 844$, pp. $754^{-6}(\mathrm{BL})$.

${ }_{27}$ India (Military) to COD, paras. $74^{-5}$, letter 7, 26 Mar. $185^{8}$, paraphrased in COD to India (Military), despatch 1101 (no. $25^{1}$ of $185^{8)}$, 30 Aug. $185^{8}$, IOR/E/4/854, pp. $1038-9$ (BL); IOR/E/4/841, p. 474 (BL); Anonymous, 'St. Mark's Church', TOI, 11 Nov. 1926, p. 12; Sutherland to COD, no. 21 of 1835,27 May 1835 , IOR/F/4/1524/60208, pp. 1-4 (BL); Anonymous, 'Bombay Port Trust', TOI, 1 Feb. 1887 , p. 5 .

28 India (Military, Public Works Department (PWD)) to COD, para. 1o, letter 3, 22 Feb. $185^{6}$, paraphrased in COD to India (Military, PWD), despatch 920(no. 163 of $185^{6}$ ), 8 Oct. $185^{6}$, IOR/E/4/839, pp. 405-6 (BL); COD to GCFSG (Military), paras. 2-3, 20 Nov. 1822 , $\mathrm{IOR} / \mathrm{E} / 4 / 927$, pp. 549-51 (BL). 
white ants among the principal agents, which caused 'half of the hedge...to be renewed annually'. ${ }^{9}$

The potential threat of white ants even added to the concerns of commercial planters. George Watts's A dictionary of the economic products of India described in 1893 that the white ants were 'enemies' of sugarcane plants. $3^{\circ}$ Official reports from the period claimed that white ants tended to 'eat up the root of the live (sugarcane) crops...and caused the death of the plants'. ${ }^{1}$ Other reports noted the 'plentiful' presence of white ants in the Indian tea gardens, where they 'occasionally' caused a 'great deal of damage', while also 'greedily attacking' groundnut plants. $3^{2}$ White ants were believed to be especially harmful to the 'young and weakly' plants, and were listed as a pest for mango trees, chilli crop, and wheat. 33

British imperial power in India was based, to a great extent, on paper and wood. These material foundations made imperial power vulnerable to white ants. By threatening the survival of paper, white ants impaired the maintenance of colonial bureaucratic, financial, intellectual, and archival processes. By threatening materials made of wood, white ants undermined various nodes of colonial state-making in the nineteenth century ranging from spectacular entities such as the customs hedge, military arsenals, ships, and railways to more nondescript electric telegraph posts and packages. Beyond the world of materials constituted of timber and paper, the spectre of white ants haunted the commercial plantations.

Towards the end of British colonial rule in South Asia, an English newspaper article claimed that losses suffered in India because of white ants were 'incalculable'. ${ }^{34}$ Officials observed that the impact of white ants on materials made of timber could also be quite misleading because these insects often 'destroyed' timber whether used in 'buildings, bridges and...furniture' from within, while leaving the exterior intact. 35 Officials were perturbed by the alleged ability of white ants to damage edifices of empire while leaving the outward illusions of order and stability undisturbed.

Colonial officials found white ants to be elusive given their miniscule size, their unpredictable origins, their preference for darkness, and their relative

29 Roy Moxham, The great hedge of India (Oxford, 2001), pp. 95-7.

$3^{\circ}$ Watt, A dictionary, p. 125.

$3^{1}$ E. P. Stebbing, 'Insects pests of the sugarcane in India', Indian Museum Notes, 5 (1903), pp. $64-91$, at p. 76.

$3^{2}$ H. Maxwell-Lefroy, Indian insect pests (Calcutta, 1906), p. 147; E. C. Cotes, 'An account of insects and mites which attack the tea plant in India', Indian Museum Notes, 3 (1895), pp. 1-71, at p. 46 .

33 Maxwell-Lefroy, Indian insect pests, p. 229; Cotes, 'An account of insects', p. 46.

34 Correspondent, 'London-Day by day', TOI, 8 Sept. 1938, p. 10.

35 D. D. Cunningham, Plagues and pleasures of life in Bengal (London, 1907), p. 142; C. F. C. Beeson, The ecology and control of forest insects of India and the neighbouring countries (Dehra Dun, $1941)$, p. $53^{8}$. 
invisibility. ${ }^{6}$ Acting against them proved to be difficult because they were 'countless', possessed 'incredible energy', and displayed remarkable persistence in rebuilding their habitats even when they were destroyed by human intervention. 37 In view of these features, white ants continued to be seen, to a great extent, as an 'indestructible' even unstoppable problem throughout the colonial period. $3^{8}$

\section{I}

The vulnerability to white ants made imperial power resilient and vigilant. The need to protect wood and paper (and plantations) from white ants provoked imperial officials to devise effective ways to govern these animate and inanimate non-humans. These techniques reinforced different facets of imperial state power.

One of the obvious manifestations of brute state power involved targeting the insect itself. The practice of killing white ants by temporarily sinking ships that were infested with these insects into the sea originated at least as early as the 1810 and persisted into the second half of the century.39 Steaming was another early nineteenth-century technique that was deployed in killing white ants in ships. $4^{\circ}$ These paved the way for other enduring processes such as fumigation of white ants' nests (also known as ant-hills; usually conical structures made of clay) with the help of various poisonous chemicals, such as hydrocyanic acid, carbon bisulphide, pure white arsenic powder, diphenylamine and calcium cyanide.$^{4}$ For the purpose of fumigation, imperial officials could access white ant killing appliances, such as the Vermin Asphyxiator, which was described in 1874 as a 'strong and durable instrument' capable of disseminating sulphurous smoke into the burrows of white ants' nests, and the Ant Exterminator, which was described in 1914 as a machine that could 'pump hot poisonous gases into the subterranean burrows or galleries' of white ants. $4^{2}$ Meanwhile, in the 1900 , a solution of corrosive sublimate was considered 'quickly fatal to all the insects', and therefore its application was recommended to prevent possible inroads of white ants into buildings. 43 In the

$3^{6}$ EHA, 'The tribes on my frontier: white ants', p. 2; Lardner, The bee, pp. $110,111,117$.

37 EHA, 'The tribes on my frontier: white ants', p. 2; Cunningham, Plagues, p. 141; Lardner, The bee, pp. 111,125 .

$3^{8}$ Correspondent, 'London-Day by day'; R. Thompson, Report on insects destructive to woods and forests (Allahabad, 1868), p. $4^{1}$.

39 William Chapman, A treatise containing the results of numerous experiments on the preservation of timber from premature decay (London, 1817), p. 149; Anonymous, 'Interesting experiment at Hog Island'.

$4^{\mathrm{O}}$ Marine Board to Bentinck, 6 Jan. 1829.

$4^{1}$ Beeson, The ecology, p. 934.

$4^{2}$ Shortt to Bidie, letter 714, 30 June 1874 , enclosed in despatch 119,16 Sept. 1875, IOR/ $\mathrm{L} / \mathrm{PJ} / 3 / 1116$, no. 119 (BL); T. Bainbrigge Fletcher, Some south Indian insects and other animals of importance considered especially from an economic point of view (Madras, 1914), pp. $121-2$.

43 Cunningham, Plagues, p. 143. 
same decade, cruder techniques persisted. White ants' nests were razed to the ground through force, burnt down, or attacked with hot water and kerosene. 44

Through much of the colonial period, these necropolitical impulses were complemented by efforts to replace the use of wood with more robust objects, such as metals, which were believed to withstand the presence of white ants. Thus, it was recommended that copper, iron, lead, or even steel should replace wood on the mast-head of ships, gun barrels, on telegraph posts and railroad ties, on windmills, and in arsenals and churches. 45 Similarly, concrete and plaster were preferred over wooden materials and thatched roofs in the construction of official buildings, and at least on one occasion it was recommended that brickwork should replace timber in the construction of a suburban railway bridge. $4^{6}$

Large-scale substitution of wood with other materials could neither be undertaken on a comprehensive scale across colonial South Asia nor was the extermination of the entire species of white ants from the region feasible. While being compelled to retain wood and paper as key ingredients of the British colonial state in India, imperial officials devised ways of protecting these materials from white ants. These strategies were broadly of two kinds, both of which contributed to the governance of these inanimate non-humans.

The first set of strategies involved applying protective layers on the external surface of paper and wood to drive white ants away. In the Company era, varnishes made of various botanical compositions including Bhella juice and bitter aloes were recommended for the protection of wooden structures such as vessels, and telegraph posts. 47 Later between the 1880 s and 19oos, paper was routinely smeared with a range of chemical entities referred to variously as Mr Woodrow's solution, kerosene oil, and 'spirituous solutions of corrosive sublimate'. $4^{8}$ In the same period, kerosene emulsions, tobacco decoctions, and strong soap solutions were applied to plants to 'dislodge' white ants. 49 Similar practices survived until the 1940 s when surfaces of wood were brushed with chemicals including coal-tar creosote, and solutions of zinc

44 Maxwell-Lefroy, Indian insect pests, p. 229.

45 Chapman, A treatise, p. ${ }_{15}$ o; IOR/E/4/927, pp. 549-51 (BL); Anonymous, 'White ants in India', Scientific American, 64 (3 Jan. 1891), p. 3; Walter T. Scudder, 'Windmills in India', Scientific American, 89 (29 Aug. 1903), p. 151; IOR/E/4/839, pp. 405-6 (BL); Anonymous, 'St. Mark's Church'.

$4^{6}$ Anonymous, 'White ants in India'; Beeson, The ecology, pp. 935-9; IOR/E/4/841, p. 474 (BL); India (Financial, Railway) to COD, paras. $38-9$, 1 Sept. 1857, paraphrased in IOR/E/4/ $85^{1}$, pp. 502-3 (BL).

47 Marine Board to governor general in council, 18 May 1816 , IOR/F/4/56o/1376o (BL); India (Financial, Railway) to COD, paras. 57 and 68 , letter 45,28 Nov. 1856 , paraphrased in COD to India (Financial, Railway), despatch $93^{8}$ (no. 39 of 1857), 2 Sept. 1857 , IOR/E/4/ 847 , p. 163 (BL).

${ }_{4}^{8}$ Home, Books and Publications, Jan. 1890, 28-34B (National Archives of India (NAI)); Cotton to secretary, Bengal (General), 8 Jan. 1883, Home, Public, Apr. 1883, 6o-2B (NAI); Cunningham, Plagues, p. 143 .

49 Maxwell-Lefroy, Indian insect pests, p. 231; Cotes, 'An account of insects', p. 6 o. 
chloride, arsenic, and chlorinated naphthalene. $5^{\circ}$ These chemicals and botanical extracts were tools of wider colonial sanitary governance that aimed to restore hygiene by relieving humans from the interference of pests. This explains why chemical solutions including carbolic acid were applied to the corners of buildings to deter the presence of white ants. ${ }^{1}$

The second set of strategies, of which different forms were visible throughout the nineteenth and early twentieth centuries, was related especially to wood, and aimed at altering and improving the internal composition of the object itself. These strategies, imperial officials hoped, would contribute to the robustness of wood. One of the probable ways of achieving this was through desiccation, which involved the removal of moisture by the application of heat. This was believed to be characterized by a 'purifying virtue' because the removal of moisture restored the robustness of the fibre of the wood, making it potentially uninflammable and durable. ${ }^{2}$ 'Metallization' was considered to be another way through which the strengthening of wood could be achieved. Indeed, British colonial officials accessed and compared different processes attributed to British innovators in Britain and India that claimed to soak, saturate, and steep pieces of wood in solutions of metals such as copper, zinc, and iron.53 For similar purposes, heterogeneous material concoctions including petroleum, coal-tar creosote, solution of corrosive sublimate and rain water, solution of volatile ammonia, and pounded oxide of arsenic, coconut oil, and saccharine were inserted within wooden structures.54 Unlike other colonial modalities of dealing with the white ant problem, these efforts were explicitly articulated in medical terms: the insertion of these materials into wood was described as an 'effectual curative process', or as an injection; while these preservatives were, on occasions, referred to as an antiseptic.55 The insertion of

$5^{\circ}$ Beeson, The ecology, p. 943 .

$5^{1}$ Cunningham, Plagues, p. 143.

$5^{2}$ COD to Bengal (Military), despatch 530 (no. 88 of $185^{\circ}$ ), 14 Aug. $18_{5}$ o, IOR/E/4/805, pp. 770, 772, 773 (BL); COD to Bengal (Military), despatch 363 (no. 62 of $185^{\circ}$ ), 3 o May $185^{\mathrm{o}}, \mathrm{IOR} / \mathrm{E} / 4 / 8 \mathrm{o} 4$, pp. 802-4 (BL); COD to governor, Bengal (Military), despatch $55^{\mathrm{O}}$ (no. 69 of 1849), 22 Aug. 1849, IOR/E/4/801, pp. 565-9 (BL); Anonymous, 'Messrs. Davison and Symington's patent method of cleansing, purifying and sweetening, casks, vats and other vessels', Mechanics Magazine, 40, 1085 (25 May 1944), pp. 338-41, at p. 338; Major Percy Smith, Rivington's building construction (London, 1875), pp. 392, 394.

53 IOR/E/4/804, pp. 802-4 (BL); Smith, Rivington's, p. 394; 'The continental patent metallized wood company', Lancet, 23 (6 June 1846), page not mentioned; Bengal (Military) to COD, para. 31, letter 27, 25 Feb. $185^{\circ}$, paraphrased in COD to Bengal (Military), despatch $53^{\circ}$ (no. 88 of $185^{\circ}$ ), 14 Aug. $185^{\circ}$, IOR/E/4/805, pp. $770,772,773$ (BL); COD to governor, Bengal (Military), despatch 272 (no. 48 of 1853), 20 Apr. 1853 , IOR/E/4/819, pp. $1195^{-7}$ (BL); COD to Bengal (Revenue), despatch 863 (no. 11 of 1846 ), 23 Dec. 1846 , IOR/E/4/ 790, pp. 1022-3 (BL).

54 Beeson, The ecology, p. 943; Chapman, A treatise, pp. ${ }_{14}^{8-} 5^{\mathrm{O}}$; An engineer, Railways in India (London, 1947), pp. 85-6; Anonymous, 'Powellization of wood', TOI, 28 May 19o9, p. 11.

55 An engineer, Railways, p. 122; Smith, Rivington's, p. 394; Anonymous, 'Powellization'; Beeson, The ecology, pp. $943,94^{6 .}$ 
these materials into wood was also described, in crude gendered language, as impregnation, or, less frequently, as penetration. $5^{6}$ British imperial officials imagined wood in India as a weak and vulnerable entity, which could potentially become stronger and durable once 'impregnated' by invigorating chemical solutions.

White ants, therefore, provoked different responses from the representatives of imperial power. Imperial officials acquired the ability to kill as well as repel white ants. They were also either able to replace inanimate victims of white ants with more durable substitutes, or to devise strategies to protect them. While ensuring the protection of paper and wood, imperial officials displayed their ability to disrupt the supposed purity and homogeneity of objects: both paper and wood were interspersed with chemicals; metallic contents became the part and parcel of the interiors of wooden structures; while botanical extracts indelibly adorned their external surfaces.

A book written in $194^{1}$ by the then forest entomologist in India, C. F. C. Beeson, suggests that this combination of techniques was in place even in the final decade of British colonial rule in India. 57 Throughout the period, there was no magic bullet that could resolve the white ant problem singlehandedly. The recurrence of white ants forced contemporaries to doubt, on occasions, some of their most established assumptions, including the supposed immunity of metals from the onslaughts of white ants. An early twentiethcentury British newspaper article claimed, for example, that 'white ants of India' could 'perforate lead'. $5^{8}$ It seems that the problem of white ants could only be negotiated through these various networks of strategies and everyday vigilance.

While official efforts to deal with white ants were never wholly successful, they had three enduring implications. The quality of objects, such as different types of wood, began to be judged on the basis of their perceived abilities to survive white ants. For example, T. Bainbrigge Fletcher, the imperial entomologist and his assistant, B. B. Ghosh, reported an experiment in 1921 that hierarchized various wood preserving processes based on their varying degrees of resilience against white ants. They concluded that pieces of wood that were 'impregnated' with hot creosote survived attacks of white ants for more than eighty-one months; those 'impregnated' with cold creosote survived less than twentyeight months; those 'painted with cold Carbolineum' lasted less than twentythree months; those 'treated with' the Powell process ('impregnation of wood with an antiseptic saccharine substance') endured less than twenty-one months; those 'immersed' in solutions of arsenate and lead successively survived

\footnotetext{
$5^{6}$ Anonymous, 'Powellization'; An engineer, Railways, p. 86, 122; Beeson, The ecology; Chapman, A treatise, pp. $14^{8-} 5^{\text {o. }}$

57 Beeson, The ecology, pp. 933-51.

$5^{8}$ Anonymous, 'Insects that perforate lead', Belper News and Derbyshire Telephone, 23 Aug. 1907 , p. 2.
} 
less than sixteen months; those 'painted with' sideroleum and microlineum lasted less than fourteen months, while those 'immersed' in a solution of zinc chloride, 'treated with' lead chromate and 'painted with' siderosthen survived less than twelve, seven, and four months respectively. 59

Government efforts to deal with white ants also reinforced the growth of a commercial market for sanitary commodities especially in the early twentieth century, which catered to a consumer base that went beyond the immediate needs of the state. Advertisements published in newspapers refer to the perpetuation of a range of commodities including mort-ant, flit, and carbolineum avenarius that were mentioned alongside phenyl, kerosene oil, sunlight soap, and eventually DDT as products capable of neutralizing white ants and their effects in private homes and offices. ${ }^{60}$

Finally, these government initiatives consolidated hands-on knowledge about the proclivities of white ants. These insights were assembled mostly by colonial officials engaged in managing the colonial state in India. They put together what can be described as a natural history-from-below by addressing everyday practical questions such as: What attracted white ants? What were the most effective ways of killing them? What turned white ants away? These officials also verified if strategies devised in metropolitan Britain were relevant in the colonial context. ${ }^{61}$ They contributed significantly to the ways in which white ants were understood and dealt with in the colony. Rather than being motivated exclusively by a desire to generate and circulate natural historical knowledge within the ivory tower, these questions were encountered while dealing with mundane administrative challenges such as protecting ships, bridges, buildings, railways, and plants in the colonies.

The entomo-political state intervened into the world of non-humans in different ways. Colonial officials killed white ants, drove them away, and in so doing, also nurtured ideas about the varying conditions in which these insects lived, thrived, or died. The governmental gaze of the entomo-political state extended beyond insects to include the inanimate victims of white ants. While claiming to protect them, colonial officials interfered with their fundamental constitutions, and contributed to their classification and hierarchy.

\section{I I}

Meanwhile, as this section will reveal, imperial discourse constructed India as a land of white ants, held India and its inhabitants responsible for the white ant

59 T. Bainbrigge Fletcher and C. C. Ghosh, The preservation of wood against termites (Calcutta, 1921 ), p. 7 ; IOR/V/25/500/126 (BL).

60 'Mort ant', TOI, 20 Feb. 1915 , p. 4; 'Flit', TOI, 6 Oct. 1926, p. 2; 'Carbolineum avenarius', TOI, 2o June 1929, p. 13; Mofussil Mary, 'The unbidden guest', TOI, 4 Feb. 1939, p. 21 ; Roland Christe, 'DDT and white ants', TOI, 4 June $195^{\circ}$, p. 2.

${ }^{61} \mathrm{IOR} / \mathrm{L} / \mathrm{PJ} / 3 / 1116$, no. 119 (BL); IOR/E/4/819, pp. $85^{8}, 1195^{-7}$ (BL). 
problem, and reinforced the civilizing rhetoric of imperial ideologues by defining white ants as a hallmark of the lack of civilization.

The nineteenth-century claim that Britain and Europe were devoid of white ants coincided with the idea that these insects were an integral feature of the tropics and the Torrid Zone, and other distant constituents of the colonial world such as Africa, the West Indies, and most notably India. ${ }^{62}$ 'White ants of India' figured as a metaphorical expression that was used to articulate political antagonism and social disapproval in contemporary Britain. Protestant clergy who allegedly failed to protect Protestantism from the Tractarians and pandered to Roman Catholicism; urban life in London itself that was described as a 'great mound of greedy emmets'; 'Unionist newspapers' with Tory sympathies which by censoring crucial details 'destroyed only the material portion of documents'; a critic of the tithes who apparently tended to 'make up for his ignorance by his destructiveness'; or political activists against corn laws were all variously compared to 'white ants of India' in British newspapers. ${ }^{63}$ These metaphorical uses suggested that real white ants were disagreeable and nonexistent in Britain, while being an inalienable characteristic of India.

White ants prominently featured within Orientalist descriptions of Indian everyday life, art, religion, and landscapes. In his multivolume illustrated work Les Hindous published in the early nineteenth century, the Flemish commentator F. Baltazard Solvyns dedicated a section to the white ant, which according to him was 'the most destructive insect known in Hindoostan'. 'Wherever it goes, corrodes everything, and eats even into metals, books, furniture, and even houses are reduced to dust. ${ }^{6}{ }_{4}$ British colonial officials-turned-naturalists such as Edward Hamilton Aitken (henceforth EHA) and D. D. Cunningham reinforced the view that white ants were an inescapable aspect of living in the subcontinent. Writing in $188 \mathrm{o}$, EHA claimed that one of the most inevitable experiences that travellers to India were bound to encounter was 'white ants eating up the bed in one night, so that in the morning we are lying on the floor'. ${ }_{5}$ The next year, EHA described India as 'a land whose soil is threefourths white ants and one-fourths earthy matter or stone'. ${ }^{66}$ Cunningham argued in 1909 that any account on common insects found in Indian

${ }^{62}$ Edwin Arnold, 'East and West: a flight of locusts', Daily Telegraph, 27 Dec. 1893, p. 7; F. Baltazard Solvyns, “'Cariar". White ants', in Les Hindous, IV (Paris, 1812), page not mentioned, $\mathrm{X}_{471 / 4(66)}(\mathrm{BL})$; Lardner, The bee, p. 99; White, Ants and their ways, p. 235; Chapman, A treatise, pp. ${ }^{1} 4^{8-} 5^{\mathrm{O}}$; Douglas and Driver, 'Imagining the tropical colony', pp. $92-4,99$.

${ }_{3}$ G. P. R. James, 'Extract from "The smuggler, a tale", Bell's New Weekly Messenger, 27 July 1845, p. 6; Anonymous, 'Agriculture and its labourers', Leeds Intelligencer, 7 Mar. 1846, p. 3; Anonymous, 'United protestant action', Brighton Gazette, 24 Dec. 1863, p. 6; Anonymous, 'Entre nous', Hackney Express and Shoreditch Observer, 13 Nov. 1886, p. 3; Henry F. Barnaby, 'To the editor', Herts and Cambs Reporter and Royston Crow, 10 Jan. 1890, p. 8.

${ }^{6}$ Solvyns, "Cariar". White ants'.

${ }_{65}$ EHA, 'The tribes on my frontier: the lizards', TOI, 4 Sept. 188o, p. 2.

${ }^{66}$ EHA, 'The tribes on my frontier: white ants', p. 2. 
gardens and houses that failed to devote attention to the white ants would be like 'a performance of Hamlet with the name-role left out'. ${ }^{67}$

Commentaries on art and sculpture either collected or authored by British colonial officials claimed that white ants and their habitats (whether referred to as nests or hills) were integrated in multiple South Asian religious traditions. ${ }^{68}$ White ants' nests or hills recurrently featured in colonial visual representations of Indian landscapes. People associated with senior representatives of the colonial state often created these visuals. ${ }^{69}$ These visual works, which included photographs, asserted the prominence of these nests in South Asian landscapes by emphasizing their significant sizes..$^{\circ}$

In explaining the proliferation of white ants and their nests in India, imperial commentators referred to the peculiarities of the place itself, apart from blaming inefficient subordinate officials, and unrefined natives. The perpetuation of white ants in the colony was explained in terms of the compatibility of these insects with Indian nature. Both white ants and India were described as integral components of the tropical world. $7^{1}$ Officials suggested that India's natural environment allowed white ants, monkeys, and birds, much like thunderstorms, to be encountered frequently. $7^{2}$ Officials also suggested that indigenous crafts especially attracted and sustained white ants. For example, revenue officials in Bombay in the 184 os made the intriguing observation that Guzerat revenue survey records that were written 'on country paper in the native characters' were particularly 'destroyed by white ants', and that the 'nature of country paper tends so much to the engendering and propagation of this pernicious insect'.73

It was suggested that white ants could destroy wood and paper because of the negligence of subordinate colonial officials. For example, on learning that a railway bridge made of creosoted timber had been damaged by the action of white ants in suburban Bengal in 1857 , the Court of Directors in London recommended that the railway engineer should investigate whether there was

67 Cunningham, Plagues, p. 140.

68 See commentaries accompanying Anonymous, 'Spectacled or Binocellate Cobra' (watercolour), c. $1802, \mathrm{NHD}_{7} / 1085$ (BL), and Edmund David Lyon, 'Views in Mysore. Shevana Bala Gola [Sravana Belgola]. The Jain statue' (photograph), c. 1868, Photo $212 / 6(5)$ (BL).

69 Frances Eden, 'White ants' nest and huts of the mahouts', Figure 18, p. 26 in 'Album of 71 drawings made on a tiger-shooting expedition in the Rajmahal Hills (Bihar) and during the journey from and to Calcutta through Bengal', Feb. and Mar. 1837, MSS Eur C1 $30 / 1$ (BL); for a glimpse of what the India Office records identify as 'A view of Jind with a small native encampment before it, and a great termite heap', see Sita Ram, 'Town and fort of Gheen with the Rajah's house', 1815 , Hastings Album 4. Add Or 4789 (BL).

$7^{\circ}$ Hugh Fraser Macmillan, 'White-ants' (termites) nest, Pallakelle', Mar. 1904, Photo $55^{1}$ (35) (BL).

$7^{1}$ David Arnold, Tropics and the travelling gaze: India, landscape and science, I80o-I856 (Seattle, WA, 2006).

$7^{2}$ COD to governor general of India-in-Council (Public), despatch 645 (no. 13 of 1849), 26 Sept. 1849 , IOR/E/4/801, pp. 1081-4 (BL).

73 Dickinson to Reid, letter $973^{8,} 3$ Dec. $1838, \mathrm{~F} / 4 / 1901 / 805_{5}^{2}$, pp. $3^{-5}$ (BL). 
any 'deficiency of creosote' in the relevant construction. It was therefore implied that the ravages caused by white ants could have been avoided if the subordinate officials were more efficient in their application of creosote. 74 Similarly, the destruction of 149 copies of Moleworth's dictionary a couple of decades earlier in Bombay was blamed not on 'oversight...but...culpable neglect' of subordinate officials.75 The ruining of currency notes by white ants in the collector's office in Monghyr in November 1835 provided occasion to criticize widespread corruption in that office. $7^{6}$

While discussing white ants, British commentators blamed the limited intellectual faculty of Indians. Discussions about strategies against white ants in India were accompanied with comments admonishing 'ignorant and sloth' domestic servants who failed to follow the instructions of their employers, and Indians more generally who lacked education and enterprise. 77 The problem of white ants provided British officials with an excuse to assert that Indians were superstitious and irrational in their religious beliefs. While a book on the agricultural pests of India claimed that white ants' nests were revered as sacred sites for worshipping serpents by the 'Hindoos', a Christian missionary text included the alleged Hindu penance ritual of 'inviting white ants to make their nests' in the body within a long discussion about 'frightful' 'childish and disgusting' religious practices in India. ${ }^{78}$ Similarly, an English newspaper article published in the 1930 os discussing white ants mocked the intelligence of 'Parsee housewives' for their irrational attempts to stave off insects by reciting religious mantras on New Year's Day.79

Meanwhile, books published from London speculated about the nature of white ants themselves and what happened within their nests. Lardner, for example, echoed most contemporary commentators by observing that nests of white ants contained different categories of such insects. The first category, according to Lardner, consisted of two individuals: a male and a female, who were the only ones that possessed vision. Their principal role was reproduction, and because of the reproductive process, the bulk of the female equalled 20,000 to 30,000 times of the second category of white ants present in the nest. Members of the second category, which according to Lardner were relatively minuscule and numerous, carried out the 'entire industrial business' of the nest including building the habitation and foraging. The third category was 'armed with long pointed mandibles' and defended the nest and the

74 COD to Financial, Railway, IOR/E/4/851, pp. $5^{\mathrm{O} 2-3}$ (BL).

$75 \mathrm{IOR} / \mathrm{E} / 4 / 1059$, pp. 963-9 (BL).

$7^{6} \mathrm{IOR} / \mathrm{E} / 4 / 754$, pp. $264^{-5}$ (BL).

77 Cunningham, Plagues, p. 145; Scudder, 'Windmills', p. 151.

$7^{8}$ Edward Balfour, Agricultural pests of India, and of eastern and southern Asia, vegetable and animal, injurious to man and his products (London, 1887), p. 111; J.W. Cunningham, Christianity in India: an essay on the duty, means and consequences of introducing the Christian religion among the native inhabitants of the British dominions in the east (London, 18o8), pp. 87-8.

79 Correspondent, 'London-Day by day'. 
reproductive couple from enemies. ${ }^{80}$ Lardner described the nest as a vast 'conical-shaped habitation', the external surface of which was made of clay, and which could be ten to twelve feet high. ${ }^{81}$ The interior of the nest, which was imagined as a subterranean network of galleries and chambers interconnected through passages, corridors, and tunnels, also had room for what were described as nurseries and store-rooms. ${ }^{82}$

In contemporary anthropomorphic imagination, the final two categories were referred to as workers and soldiers respectively. They were considered as 'inferior members', 'faithful subjects' devoid of vision, and therefore blindly serving the reproductive couple, which were described as king and queen. Lardner described the royal couple as 'privileged individuals' receiving the 'respect...attendance and honours, due to sovereigns' and who were 'exempted from participation in all the common industry' of the nest, apart from 'increase and multiplication' ${ }^{8} 3$

In similar anthropomorphic vein, white ants' nests were frequently mentioned as a 'colony'. ${ }^{4}$ The white ants, as we have noted, were allegorically imagined to constitute a parallel, often underground, world of 'dominion' and 'sovereignty'. Although these nests were lauded for their astute organization, ${ }^{85}$ British Indian officials-turned-naturalists considered them sinister. Writing for the Times of India, EHA referred to these colonies as 'miniature volcanoes', and called their insect inhabitants 'the arch scourge of humanity...blight of learning...destroying hordes', comparing them with defiant pre-medieval conquerors such as the Ostrogoths, Huns, and Vandals, rather than self-styled 'liberal' colonists of the Victorian era. ${ }^{86}$ Humorous descriptions of the queen of white ants' colonies by these authors were colored with misogyny and racism. They also reflected Malthusian anxieties about overpopulation in famine-stricken British colonies. Cunningham, for example, referred to the reproductive female in the white ant colony as a 'disgusting queen'.87 EHA mocked the queen by likening her with a 'sausage' producing 80 ,ooo eggs a day. He compared the queen of the colony of white ants with the 'fat wives' of the rebel Zulu king, Cetewayo. ${ }^{88}$ In many ways, the white ant colony was imagined as a subversion of the lofty ideals of Victorian culture

8o Lardner, The bee, pp. 98-103, 125 .

81 Ibid., p. 103 .

82 Ibid., pp. 98, 104 .

83 Ibid., p. 99; see also Clark, Bugs, p. 6.

84 Lardner, The bee, p. 98; Cunningham, Plagues, p. 145; EHA, 'The tribes on my frontier: white ants', p. 2.

85 Sleigh, 'Empire of the ants', pp. 34, 36.

86 EHA, 'The tribes on my frontier: white ants', p. 2.

87 Cunningham, Plagues, p. 145.

88 EHA, 'The tribes on my frontier: white ants', p. 2. On social allegories of female insects in a later period, see Charlotte Sleigh, 'Inside out: the unsettling nature of insects', in Brown, ed., Insect poetics, pp. 288-97. 
and political stability that the British were promising to introduce in colonial India.

Contemporary writers in the imperial age, many of them British, appropriated the question of white ants to assert civilizational differences. They agreed that while British colonial interests discarded white ants as a harmful pest, inhabitants of 'the east', and of parts of 'India as in Africa' knew how to make use of white ants. It was observed that these people accepted white ants as objects of food. ${ }^{89}$ One author suggested that while insect-eating had precedents in different civilizations in previous historical epochs, these practices eventually survived more extensively beyond Western Europe and among the 'savage nations'.90 An article published in the Scientific American in 1891 entitled 'White ants in India' implied that in consuming white ants, 'the Africans' shared the eating preferences of lizards, toads, and birds. $9^{1}$ Even when encouraging their compatriots to eat insects (including white ants), British writers acknowledged that many contemporaries considered these practices a marker of the lack of civilization. The entomologist in the imperial department of agriculture for India, H. Maxwell-Lefroy, claimed in 1909 that eating insects reflected the 'expertness of the little-civilised portion of mankind', and that 'people who practise this habit are not those of whom...civilisation reaches' $.9^{2}$

Before he acquired his notoriety as the pioneer of eugenics, Francis Galton had written a travellers' manual, first published in 1855 , in which he argued that natives of 'wild countries' (as distinct from 'civilised and partly civilised nations') dug holes 'in the sides of' white ants' nests and used them as ovens for the purposes of cooking. ${ }^{93}$ Another travel narrative published in London in 1912 claimed that the 'negroes' of West Africa perpetrated 'ghastly forms of torture' by forcibly fastening humans to white ants' nests. The author observed that it was not unusual in the region to find skeletons of humans tied to nests, ten to twenty feet high.94

These writers believed that unlike what was to be expected in contemporary 'civilised England', 95 white ants were integrated within various social practices of the 'Negroes' of West Africa, in the so-called wild countries and in 'the east'. An article in the American Naturalist in 1876 argued that advancement of 'culture' was antithetical to the proliferation of white ants. It claimed that in Africa and India, 'where a century ago massive ant-hills were to be found

\footnotetext{
89 H. Maxwell-Lefroy, Indian insect life (Calcutta, 1909), p. 277; Lardner, The bee, p. 101; Vincent M. Holt, Why not eat insects? (London, 1885), p. 55 .

$9^{\circ}$ Holt, Why not, pp. 33, 47 .

$9^{1}$ Anonymous, 'White ants in India'.

$9^{2}$ Maxwell-Lefroy, Indian insect life, p. 276; Holt, Why not, pp. 32-3, 47.

93 Francis Galton, The art of travel; or shifts and contrivances available in wild countries (4th edn, London, 1867), pp. iv, 205 .

94 Mary Gaunt, Alone in West Africa (London, 1912), pp. 194-5.

95 Francis Galton, The art of travel; or shifts and contrivances available in wild countries (2nd edn, London, $\left.185^{6}\right)$, p. iii.
} 
near the shore, now some days' journey inland have to be made to find them'. This period, according to the article, coincided with the 'step by step...retreat of white ants...in front of a rapidly advancing culture', when 'mankind' took control over white ants, forcing this representative of 'nature (to) step behind'. Therefore, the hundred-year period that marked among other developments the advent of colonial rule in Africa and India, this article implied, went hand in hand with 'the advance of culture' and the 'retreat of white ants'. $9^{6}$

Meanwhile, in India, white ants were described by British naturalists like EHA as 'the foe of civilization...the Goths... of Indian life'. 97 The title of EHA's book The tribes on my frontier: an Indian naturalist's foreign policy, first published in 1881 , which contains a chapter on white ants, is revealing. $9^{8}$ In colonial ethnographic discourse, tribes were constructed as primitive savages, who were believed to inhabit the outskirts of civilized colonial rule. Therefore, greater control and extension of the frontiers of empire was often justified in terms of the need to incorporate the tribes more firmly within the sphere of modernity and civilized governance.99 The frontier was also imagined as a threshold where encounters with the uncanny, the unknown, and the unfamiliar became more frequent. The inclusion of white ants as one of the 'tribes on my frontier' meant that the insect was deployed as a metaphor for the supposedly unruly and uncivilized subjects inhabiting the peripheries of imperial control. The title deliberately suggests a link between the 'foreign policies' of the British naturalist and the British imperialist, implying that the grasp of nature by culture, the domination of non-humans by humans, and the conquest of the so-called tribes by the ostensibly civilized were analogous processes. ${ }^{100}$

Thus, control of white ants (and the protection of wood and paper) was not merely a necessity to ensure the unhindered functioning of British colonial power, but more intimately entangled with the fundamental civilizing ideologies of empire itself. Backed with such ideological certitude, British officials advocated the destruction of white ants in the most evocative language. EHA, for example, described the 'wholesale slaughter of white ants' by bats, owls, kites, and crows as 'the great crusade' which these animals joined, 'washing out...the scandal of their past lives'. ${ }^{101}$ Other writers described government

$9^{6}$ Hagen, 'The probable danger', pp. 409-10.

97 EHA, 'The tribes on my frontier: white ants'.

$9^{8}$ EHA, The tribes on my frontier: An Indian naturalist's foreign policy (London, 1904).

99 For example, Gertrude M. Godden, 'Naga and other frontier tribes of north-east India', Journal of the Anthropological Institute of Great Britain and Ireland, 26 (1897), pp. 161-7; Elizabeth Kolsky, "The colonial rule of law and the legal regime of exception: frontier "fanaticism" and state violence in British India', American Historical Review, 120 (2015), pp. 1218-46.

${ }^{100}$ On white ants and colonial metaphors in other contexts, see Douglas and Driver, 'Imagining the tropical colony', pp. 106-8, 109-10; Clark, Bugs, pp. 2-3.

${ }_{101}$ EHA, 'The tribes on my frontier: white ants'. 
efforts against white ants as resistance, a fight, and war against a 'public enemy'. ${ }^{102}$

White ants also provoked colonial apologists, on occasions, to propose more heinous forms of widespread servitude than was explicit in British India in the second half of the nineteenth century. For example, in 1859, an anonymous newspaper entry lamented the absence of slave labour in the subcontinent. The author claiming to be 'one who has been a sugar planter both in East and West Indies' argued that this absence of slaves would frustrate the ability of plantation interests in India to compete with planters in countries such as Cuba, where slavery existed at the time. The author argued that ravages caused by white ants to agriculture in India, coupled with a thoroughly inadequate irrigation network, could only be compensated by the relentless hard work performed by slave labour, because 'the sable African under coercion in a tropical climate is the most efficient cultivator, when directed by the skill, enterprise, and intellect of the white man'. ${ }^{103}$

\section{V}

South Asians shared the British imperial practice of describing white ants as sinister creatures, even when representing their own political agendas and institutions. The pioneering Bengali novelist Bankimchandra Chattopadhyay's iconic work Ananda math had a principal protagonist who argued that feeding on 'white ants' earth' (probably referring to the white ants' nests that were made of clay) was a prominent symbol of the impoverishment of Hindu subjects under 'Muslim rule' prior to the consolidation of British colonialism in the Indian subcontinent. ${ }^{104}$ Similarly, as the historian Mushirul Hasan suggests, the nineteenth-century intellectual Nazir Ahmad compared factors that contributed collectively to the undermining of 'shariat' laws and the loss of Islamic identity in South Asia with white ants. ${ }^{105}$

The legacies of British symbolic uses of white ants can be traced in post-colonial scholarly literature on India, at times authored by South Asians themselves. In 1941, Percival Christopher Wren, who had been earlier employed at the

${ }^{102} \mathrm{IOR} / \mathrm{E} / 4 / 801$, pp. 1081-4; Anonymous, 'A war against white ants', TOI, 17 Apr. 19O2, p. 4; Anonymous, 'Fighting the white ant', TOI, 26 Apr. 1912, p. 6; Anonymous, 'A public enemy', TOI, 6 Feb. 1936, p. 10.

103 Anonymous, 'Cultivation of sugar', Morning Post, 29 Dec. 1859, p. 3. Contemporary writers with alternative opinions invoked insects to indict slavery as well. See James Moore, 'Darwin's progress and the problem of slavery', Progress in Human Geography, 34 (2010), p. 580.

104 Bankimchandra Chattopadhyay, Ananda math (5th edn, Calcutta, 1892), p. 25. On his politics, see 'preface to the second edition'. Also, Tanika Sarkar, 'Imagining a Hindu nation: Hindu and Muslim in Bankimchandra's later writings', Economic and Political Weekly, 29 (14 Sept. 1994), pp. 2553-61.

${ }_{105}$ Mushirul Hasan, A moral reckoning: Muslim intellectuals in nineteenth-century Delhi (Delhi, $2012 / 2007)$, p. $15^{6}$. 
colonial Indian educational service, wrote a short story called 'White ants'. ${ }^{106}$ Set in 'a village in western India', this story uses the metaphor of white ants in two contradictory ways. First, the story describes Indian participants at the lower level of the colonial judicial apparatus as corrupt and evil. Wren symbolically compared these Indians with white ants, which made the 'wooden pillars' of suburban courthouses vacuous, and therefore rendered the foundations of colonial law and justice dysfunctional.

But, more revealingly, the story also anticipates that Indian nationalists could appropriate white ants as a metaphor for British imperialism itself. In an electrifying speech in the story, a fictitious Indian nationalist leader, Mohandas Lala Misra, is heard stating that behind 'their covering or façade of justice' and 'their protective crust of talk and show of education, sanitation' and administration, the colonial government 'are slaying the Soul of a People, as secretly, but as surely and terribly, as the white ant insects destroy material things' ${ }^{107}$

This second possibility hinted by Wren reappeared in an article authored by Indian academic Ganesh Prasad in 196o. The author compared the traditional village, 'only the skeleton' of which 'survived the techno-economic conquest under British rule', with a hollow tree the core of which had been eaten up by white ants. 'The white ants had eaten the one; the White Sahebs had damaged the other's soul beyond repair.' 108

Meanwhile, apart from being perceived as detrimental to colonial governance, real white ants began to be seen as a threat to various symbols of the emerging Indian nation. Municipal corporations, which were local civic bodies set up by the colonial government in key urban centres, increasingly accommodated Indian representatives in the second half of the nineteenth century, and became institutions where the first generation of Indian nationalists could assert their influence. ${ }^{109}$ White ants made their presence felt in these institutions from the 188 os onwards. In a meeting of the Bombay municipal corporation held on 10 December 1888 , which was dominated, at least numerically, by South Asian members, white ants were alleged to have destroyed stationery belonging to the municipality. ${ }^{10}$ In a similar meeting a few years later, an Indian member of the Bombay municipal corporation moved a resolution pointing out that white ants had damaged the cables required to install electric lights at the municipal office. ${ }^{11}$ White ants continued to keep Indian officials at

106 Percival Christopher Wren, 'White ants', in Odd but even so- stories stranger than fiction (London, 1941); H. F. Oxbury, 'Wren, Percival Christopher (1875-1941)', Oxford dictionary of national biography.

${ }^{107}$ Wren, 'White ants', p. 3.

108 Ganesh Prasad, 'Eclecticism in modern India', Indian Journal of Political Science, 21 (1960), pp. 233-42, at p. 239 .

109 For example, Prashant Kidambi, 'Nationalism and the city in colonial India, Bombay, c. 189o-1940', Journal of Urban History, $3^{8}$ (2012), pp. 950-67.

110 Anonymous, 'Bombay municipal corporation', TOI, 11 Dec. 1888, p. 6.

111 Anonymous, 'Bombay corporation', TOI, 11 Oct. 1901, p. 3. 
the municipality busy even after the formal end of British colonial rule in $1947 .{ }^{12}$ White ants, allegedly, interfered with post-colonial governance. Newspaper reports from the $195^{\circ}$ and 1960 s refer to instances in which white ants were blamed for damaging property belonging to government hospitals, disrupting provincial elections by eating into ballot boxes and ballot papers, and for destroying stocks of wheat by making their way into government-owned 'godowns'. ${ }^{113}$

Even metaphorical uses of white ants have persisted until very recent times. Campaigning for the Himachal Pradesh assembly elections in November 2017, the Indian prime minister Narendra Modi compared his political adversary, the Congress, to white ants. 'If you clean just on the surface...termites come back after a few days... The Congress party's depraved mentality is like termites. You cannot just change the government and expect to be done with it, you have to take them out from the roots. Only then we can free Himachal of this disease', he said. ${ }^{114}$

At the same time, post-colonial India also witnessed newer trends. Indeed, in what appears to have been a break from predominant nineteenth-century British imperial discourse, white ants' nests in late colonial South Asia were upheld by some as an ideal model in a deeply conflicted and changing world. South Asian writers as well as those who described themselves as AngloIndians, too, contributed to these newer trends, and in so doing articulated their specific political contexts and ideological biases.

S. H. Prater, a former curator of the Bombay Natural History Society, was the president of the Bombay presidency branch of the Anglo-Indian and Domiciled European Association between 1930 and 1947, and its representative to the Bombay Legislative Council until 1947. After the end of British rule in India, he was elected to the Indian Constituent Assembly in 1948 as a representative of the Anglo-Indian community. He wrote an article on white ants, which was published in the Times of India in December 1947. In a year marked by decolonization and continuing communal riots across South Asia, Prater, an elected representative of a minority community in South Asia, echoed an article authored by one Major B. Hocking of the Ordnance laboratories in Cawnpore two years earlier to argue that white ants could serve as a model for 'harmonious' existence. ${ }^{115} \mathrm{He}$ suggested that the 'harmonious life' within

112 Christe, 'DDT'.

113 Anonymous, 'New insecticide for white ants', TOI, 28 May 1950, p. 15; Anonymous, 'White ants delay election results', TOI, 1 Feb. 1952, p. 5; Anonymous, 'White ants eat ballot papers', TOI, 6 Mar. 1955, p. 1; Anonymous, 'Termites eat up unsold wheat', TOI, 3 Dec. 1960 , p. 1.

${ }_{114}$ 'Congress like termites, wipe them out, says PM Modi in Himachal', NDTV, 4 Nov. 2017 , www.ndtv.com/india-news/himachal-pradesh-assembly-elections-201 7-congress-like-termiteswipe-them-out-says-pm-narendra-odi-i-1 771145 .

115 S. H. Prater, 'The social system of termites or white ants', TOI, 28 Dec. 1947, p. 4; B. Hocking, 'Entomology and war', Indian Journal of Entomology, 7 (1945), pp. 1-3, at p. 2. 
the white ants' nest was achieved through 'the ideals of communism fulfilled to the letter'. Prater observed that each individual (the queen, the king, workers, soldiers, etc.) worked uniformly and carried out their designated functions for 'common welfare and good'; there was no 'differentiated scale of wages' and each individual had their 'share in the products of the community as a whole'. Prater denied that there was a ruling class in the white ants' nest, suggesting that every individual had 'equal status', and that even kings and queens were 'sovereigns only in name'. They, like other inhabitants of the nest, argued Prater, 'are but cogs in the communal machine, where each individual becomes a mechanical unit, completing its appointed task and receiving its share of food'. The view that the queen's sovereignty and privilege were tempered by her captive status within the royal cell existed in the nineteenth century. Yet, the idea that the organization of insect life within the white ants' nest reflected a vision of communism, characterized by 'amicable division of labour' and dissolution of hierarchies, appears to have been relatively recent. ${ }^{116}$

In post-colonial India, the celebration of white ants' nests as a model for communism, as evident in Prater's article, seems to have acquired an enduring afterlife. However, this idea could be appropriated to endorse contradictory social practices. In his presidential address to the 'international symposium on termites in the humid tropics' held in New Delhi in October 196o, Mithan Lal Roonwal, who was the president of the Zoological Society of India, returned to this theme, describing white ants' nests as 'nature's first experiment in large scale socialism'. ${ }^{11} 7$ Revealingly, he combined this discussion with a celebration of the 'caste system' amongst insects. Discrimination between humans on the basis of the caste system has been one of most violent aspects of South Asian society, and this necessitated significant political protests in colonial and post-colonial India. While there was a long tradition within natural history of referring to different categories of white ants as 'castes', it is highly unlikely that Roonwal was oblivious to the sociological implications of 'caste' in the contemporary Indian context. 'Culturally, the study of the termite society, which has a rigid caste system, is of the greatest interest to human social organization', he argued. He found it commendable that white ants 'ungrudgingly' participated in a caste-based division of labour. He linked the supposed 'social harmony' amongst white ants with their voluntary participation in a leaderless 'rigid caste system', praising the fact that each category of white ants functioned according to the ways that were preordained from their

\footnotetext{
On Prater, see Salim Ali, 'Stanley Henry Prater', Journal of the Bombay Natural History Society, 57 (1960), pp. 637-42.

116 Prater, 'The social system'; Prater's comparison of the organization within the white ants' nest with communism was not entirely original. For a far less sympathetic take on the similarities between communistic principles and the white ants' nest, see Maurice Maeterlinck, The life of the white ant (New York, NY, 1927), pp. 69, 161-4.

${ }_{117}$ M. L. Roonwal, 'Address by the president', in International symposium on termites in the humid tropics, Proceedings of New Delhi symposium (Paris, 1962), p. 10.
} 
birth. ${ }^{118}$ In justifying the caste system among white ants he condoned, and probably mirrored, the discriminatory spirit in which caste systems were prevalent in human society.

The idealization of white ants in contemporary India could be even more explicit. Towards the end of the Nehruvian period, the Times of India published a piece that praised white ants for constructing exemplary polities. It argued that the world of white ants was characterized by ideological values, which humans should emulate. Thus, according to this piece, the white ants were 'pure republicans'; they constituted a world marked by the 'highest forms of democratic socialism', and the absence of 'linguistic or cultural feuds', or Cold War 'between one ism and another'. It acknowledged that 'even if some casteism' existed it was 'regularly kept under check', and even if wars were 'occasionally fought', peace was 'soon restored regardless of the price'. White ants, according to this piece, seem to have removed some of the impediments towards effective governance, such as verbose arguments about the relative merits of 'private and public sectors', revolutionaries and beatniks. 'All the angry young termites were liquidated aeons ago.' ${ }^{119}$ The world of white ants, it implied, displayed some of the contradictions characteristic of many strong, independent and modern nation-states: democracy, peace and stability co-existing with intolerance towards political dissent. Many of these ideals were drawn from the political vocabulary recurrent in contemporary India. The world of white ants was upheld as a utopia, which reflected values that the author, one might speculate, desired the fledgling Indian nation to represent.

This article has shown that white ants added to the chaos of colonial governance by interfering with the political domains of bureaucracy and infrastructure. ${ }^{120}$ Although white ants may not have considered themselves as anti-imperial actors, their activities, in effect, inhibited the consolidation of imperial power. The vantage point of entomo-politics enables historians to contest any surviving myth about the uncompromising completeness of imperial power. At the same time, self-awareness of vulnerability did not make the colonial state weaker, or generally indecisive. ${ }^{121}$ On the contrary, the white ant problem reveals that colonial power in India was founded on an increasingly deep-rooted state

\footnotetext{
118 Ibid., pp. 9-10.

119 Anonymous, 'Go to the white ant, sluggard', TOI, 9 Oct. 1960, p. 8.

120 On chaos and empire, see Jon Wilson, India conquered: Britain's raj and the chaos of empire (London, 2016).

121 In fact, accounts of vulnerability could be invoked to justify and even co-exist with violent imperial aggression. See Kim Wagner, "Treading upon fires": the "mutiny"-motif and colonial anxieties in British India', Past and Present, 218 (2013), pp. 159-97, at pp. 171-2, 175, 191, 193, 194; Ranajit Guha, 'Not at home in empire', Critical Inquiry, 23 (1997), pp. 482-93. On violence and vulnerability, see Wilson, India.
} 
that was vigilant about numerous nodes where the cherished stability of British rule could be ruptured. Thus, the infinitesimal presence of white ants was tracked in a range of sites including governors' houses, railway carriages and bridges, ships, hedges, and telegraph posts, and even in the underground galleries and chambers of insects' nests. The white ant problem made the colonial state more resilient and intrusive. The sphere of strict governmental intervention was extended to include both animate and inanimate non-humans, while the issue of white ants was appropriated to stereotype colonized landscapes, peoples, and cultures. Nonetheless, entomo-political encounters in South Asia were not entirely within the control of the colonial state. Despite effective interventions of the state, white ants did not vanish altogether, and remained objects of everyday control until the final decade of colonial rule and after. Meanwhile, colonized and post-colonial South Asians used white ants to articulate their own distinct political agendas.

Focus on entomo-politics also highlights some of the key material foundations of colonial power in British India in the long nineteenth century. ${ }^{122}$ White ants came to the attention of colonial officials because they ostensibly 'ate into' wood and paper, which were considered among the essential ingredients on which colonial rule in India was founded. These materials therefore acquired political significance, and protecting them from white ants became a priority for the government and its representatives. Seen from the perspective of white ants, empire appears to have been a 'power-saturated material-discursive'123 assemblage, sustained by materials like wood, paper, varnishes, metallic particles, protective and poisonous chemicals, on the one hand, and hierarchical discourses of race, place, and civilisation, on the other.

Finally, the history of entomo-politics examined in this article contests the notion that insects belonged purely to the domain of natural life. ${ }^{124}$ In his Insect media, Jussi Parikka points out, citing the philosopher Rosi Braidotti, that life (including insect life) 'is the double articulation of bios (politics and discourse) and zoe (nonhuman intensity), a continuous intensive creation that is also continuously articulated on a social level of power and knowledge'. ${ }^{125}$ Historians have begun to explore the political, cultural, and epistemological contexts in which the lively natural characteristics of insects were studied, recognized, and exploited. ${ }^{126}$ They have contributed to an approach

\footnotetext{
122 On paper, for example, see Raman, Document Raj; Guyot-Rechard, 'Tour diaries'. On wood in another imperial context, see Alan Mikhail, Nature and empire in Ottoman Egypt: an environmental history (Cambridge, 2011 ), pp. 124-68.

123 Hugh Raffles, 'Towards a critical natural history', Antipode, 37 (2005), pp. 374-8, at p. 377. On the enmeshes of materials and politics, see also Tony Bennett and Patrick Joyce, eds., Material powers: cultural studies, history and the material turn (Abingdon, 2010); Bruce Braun and Sarah J. Whatmore, eds., Political matter: technoscience, democracy and public life (Minneapolis, MN, 2010).

${ }^{124}$ For example, Hagen, 'The probable danger', pp. 409-10.

125 Parikka, Insect media, p. xxiv.

126 Clark, Bugs; Sleigh, Six legs better, Melillo, 'Global entomologies'.
} 
that, following the anthropologist Hugh Raffles, can be referred to as 'critical natural history', that takes 'seriously both the "natural" and the "historical", and their inter-relationships. ${ }^{127}$ Building on these insights, this article has drawn attention to the ways in which insects were, as Donna Haraway would suggest, 'natural-cultural' creatures, which belonged exclusively to neither domain. ${ }^{128}$ The natural properties of white ants, to a great extent, were experienced, recorded, and restrained by colonial officials. In controlling white ants, colonial governmental officials also consolidated and shared their knowledge of the conditions in which white ants thrived and perished. White ants featured in memoirs of officials-turned-naturalists, in colonial literary fiction, and were commissioned as subjects of art. White ants were used as a flexible metaphor to articulate a myriad of political positions: Thus, human association with white ants was claimed to be a marker of primitive civilizations and Islamic misrule; the ostensible social organization of white ants was compared in various moments with British imperial exploitation, communism, democratic socialism, and even the Indian National Congress. A history of entomo-politics in colonial and post-colonial South Asia thus reveals that insects such as white ants were shaped by, and traversed, the porous domains of nature, culture, and politics.

${ }_{127}$ Raffles, 'Towards', p. 375 .

128 Donna Haraway, When species meet (Minneapolis, MN, 2008), pp. 25, 47, 62. 